\title{
CMS Releases Data on Drug Spending
}

Yesterday (11/14/16) the Centers for Medicare and Medicaid Services (CMS) released data on spending for drugs under Medicare and Medicaid $(1,2)$. Medicare paid $\$ 137.4$ billion on drugs covered by its prescription drug benefit in 2015. About $\$ 8.7$ billion of that spending occurred on drugs that had "large" price hikes, defined as a more than 25 percent increase between 2014 and 2015. In 2015 , Medicaid paid $\$ 57.3$ billion about $\$ 5.1$ billion of which was spent on drugs that had large price increases.

The Medicare spending database highlights 11 drugs that doubled in price. The Medicaid database identified 20 drugs that more than doubled in price with 9 of these being old, generic drugs. Medicare drugs were led by Glumetza, a Type 2 diabetes drug which saw its price soar 380 percent and hydroxychloroquine sulfate, a generic malaria drug, which went up 370 percent. Medicaid drugs were led by Ativan, an anti-anxiety medication approved in 1977, which increased by 1,264 percent in price between 2014 and 2015. Daraprim, a decades-old antiparasitic drug that helped spark political attention to the issue of high drug prices after former pharmaceutical executive Martin Shkreli hiked the price, leapt up in average cost by 874 percent.

However, drugs commonly used in respiratory diseases also increased in price. These were led by mitomycin, an anticancer drug sometimes used in lung cancer, an antidepressant also used as a smoking cessation aid (Table 1).

Table 1. Medicare Spending on Respiratory Drugs.

\begin{tabular}{|c|c|c|c|c|c|c|c|}
\hline Brand Mame & Generic Name & Total Spending & $\begin{array}{c}\text { Beneficiary } \\
\text { Count }\end{array}$ & $\begin{array}{c}\text { Total Annual } \\
\text { Spending Per } \\
\text { User }\end{array}$ & $\begin{array}{c}\text { Average Annual } \\
\text { Beneficiary Cost } \\
\text { Share }\end{array}$ & $\begin{array}{c}\text { Change in Average } \\
\text { Total Spending Per } \\
\text { Beneficiary }\end{array}$ & $\begin{array}{c}\text { Change in } \\
\text { Average Cost } \\
\text { Per Unit* }\end{array}$ \\
\hline Accuneb: Albuterol Sulfate & Albuterol Sulfate & $\$ 20,603,233$ & 516,660 & $\$ 39.88$ & $\$ 10.17$ & $16.6 \%$ & $25.6 \%$ \\
\hline Advair Diskus & Flutica sone/Salmeterol & $\$ 2,270,015,726$ & 1.321 .483 & $\$ 1,717.78$ & * & $7.2 \%$ & $6.5 \%$ \\
\hline Alimta & Pemetrexed Disodium & $\$ 547,767,946$ & 21,948 & $\$ 24.957 .53$ & $\$ 4,732.54$ & $2.6 \%$ & $1.5 \%$ \\
\hline Aranesp & Darbepoetin Alfa In Polysorbat & $\$ 294,317,556$ & 58.290 & $\$ 5,049.19$ & $\$ 1.034 .46$ & $11.4 \%$ & $7.9 \%$ \\
\hline Brovana & Arformoterol Tartrate & $\$ 178,698,319$ & 68,624 & $\$ 2,604.02$ & $\$ 553.43$ & $19.2 \%$ & $16.8 \%$ \\
\hline Depo-Medrol; Methylprednisolone Acetate & Methylprednisolone Acetate $(40 \mathrm{ma})$ & $\$ 9,771,022$ & $1,235,507$ & $\$ 7.91$ & $\$ 1.86$ & $20.5 \%$ & $19.3 \%$ \\
\hline Depo-Medrol; Methylprednis olone Acetate & Methylpredn isolone Acetate $(80 \mathrm{mq}$ ) & $\$ 11,505,875$ & 962,804 & $\$ 11.95$ & $\$ 2.92$ & $15.8 \%$ & $15.8 \%$ \\
\hline Gammaqard Liquid & Immun Glob G (IGG)/Gly/laa 50+ & $\$ 264,248,241$ & 11,713 & $\$ 22,560.25$ & $\$ 4,548.91$ & $8.0 \%$ & $-0.7 \%$ \\
\hline Gammaked; Gamunex; Gamunex-C & Immun Glob G (IGG)VGly/lqa 50+ & $\$ 288,619,654$ & 10.485 & $\$ 27.526 .91$ & $\$ 5,508.32$ & $7.2 \%$ & $0.3 \%$ \\
\hline Gemcitabine $\mathrm{HCl}$; Gemzar & Gemcitabine $\mathrm{HCl}$ & $\$ 8.837 .378$ & 20,021 & $\$ 441.41$ & $\$ 91.54$ & $16.3 \%$ & $18.0 \%$ \\
\hline Mitomycin & Mitomycin & $\$ 15,768,476$ & 20,903 & $\$ 754.36$ & $\$ 154.97$ & $178.2 \%$ & $163.1 \%$ \\
\hline Neulasta & Peqfilarastim & $\$ 1,259,962,339$ & 96,562 & $\$ 13,048.22$ & $\$ 2,635.00$ & $9.5 \%$ & $8.6 \%$ \\
\hline Perforomist & Formoterol Fumarate & $\$ 79,657,563$ & 27.481 & $\$ 2,898.64$ & $\$ 612.04$ & $19.3 \%$ & $20.8 \%$ \\
\hline Prevnar 13 & Pneumococcal 13-Valent Vacaine & $\$ 914,629,739$ & $5,698,568$ & $\$ 160.50$ & $=$ & $11.1 \%$ & $10.5 \%$ \\
\hline Spiriva & Tiotropium Bromide & $\$ 2,191,465,784$ & $1,142,131$ & $\$ 1,918.75$ & * & $7.7 \%$ & $9.5 \%$ \\
\hline Wellbutrin XI & Bupropion $\mathrm{HCl}$ & $\$ 55,167,292$ & 5,336 & $\$ 10,338.70$ & * & $131.0 \%$ & $109.5 \%$ \\
\hline & Rivaroxaban & $\$ 1,524,438,227$ & 727.763 & $\$ 2,094.69$ & * & $24.9 \%$ & $12.3 \%$ \\
\hline \multirow[t]{2}{*}{ Xolair } & Omalizumab & $\$ 272,631,823$ & 13,302 & $\$ 20,495.55$ & $\$ 4.178 .63$ & $6.7 \%$ & $8.2 \%$ \\
\hline & & & Averape & $\$ 7,590.35$ & 54.178 .63 & $26.5 x$ & $252 x$ \\
\hline
\end{tabular}

The data on price on small prices rises can be deceiving when calculating total costs. For example, Advair Diskus, a bronchodilator, ranked in the top-five of Medicare expenditures, with $\$ 2.3$ billion in spending in 2015. However, he utilization of the drug has actually declined a little over the last five years. Meanwhile, the total spending has not gone down, but increased. Fueled by relatively modest price increases, from $\$ 3.81$ per unit in 2011 to $\$ 5.28$ in 2015, the spending on the drug increased by more than half a billion dollars over that period. 
Of particular concern is a rise in price of some generics, a class of drugs that are intended to decrease drug prices and spending. Drugs that were responsible for large amounts of overall spending tended to see smaller increases that gradually increased the government outlay. In one outlier, the price of the hepatitis $\mathrm{C}$ treatment, Harvoni, decreased slightly in 2015, even as it led overall spending.

The prices do not include the impact of rebates, which are prohibited by law from being released (3). Those discounts can be significant, and not knowing what they are means the numbers almost certainly overstate how much the government actually paid for these drugs. CMS disclosed that, on average, rebates for brand name drugs were 17.5 percent for medicines covered by Medicare's "part D" prescription drug benefit in 2014.

Richard A. Robbins, MD

Editor, SWJPCC

\section{References}

1. CMS. 2015 Medicare drug spending dashboard. Available at: https://www.cms.gov/Research-Statistics-Data-and-Systems/StatisticsTrends-and-Reports/Information-on-Prescription-Drugs/2015Medicare.html (accessed 11/15/16.

2. CMS. 2015 Medicaid drug spending dashboard. Available at: https://www.cms.gov/Research-Statistics-Data-and-Systems/StatisticsTrends-and-Reports/Information-on-Prescription-Drugs/2015Medicaid.html (accessed 11/15/16).

3. Johnson CY. Drugs for hepatitis $C$ and diabetes drove Medicare spending in 2015. Washington Post. November 14, 2016. Available at: https://www.washingtonpost.com/news/wonk/wp/2016/11/14/the-drugsdriving-up-medicare-spending/ (accessed 11/15/16). 